\title{
SARANA REKREASI AIR DI BEKASI SELATAN
}

\author{
Karen Rafaela ${ }^{1)}$, Petrus Rudi Kasimun²) \\ 1) Program Studi S1 Arsitektur, Fakultas Teknik, Universitas Tarumanagara, karenrafaelaw@gmail.com \\ 2) Program Studi S1 Arsitektur, Fakultas Teknik, Universitas Tarumanagara, rudi.kasimun@gmail.com

\begin{abstract}
Abstrak
Perkembangan penduduk yang pesat di era sekarang ini menyebabkan kepadatan penduduk yang terus meningkat. Dalam kehidupan sehari-hari, kita mengenal istilah firstplace (rumah) dan second-place (tempat bekerja/sekolah). Seiring perkembangan jaman, masing-masing fungsi dari first-place dan second-place seringkali menyatu dan pada akhirnya tidak memiliki pemisahan fungsi yang jelas diantara keduanya. Dari permasalahan tersebut, terbentuklah third-place untuk menjadi ruang perantara antara first-place dan second-place untuk mewadahi aktivitas yang seharusnya dilakukan di luar kedua tempat tersebut. Bekasi sebagai salah satu kota terpadat di Indonesia memiliki sumber potensi besar seperti Saluran Irigasi kalimalang yang dapat dimanfaatkan sebagai sarana rekreasi dan juga pengolahan air sebagai wadah edukasi bagi masyarakat dan memanfaatkan teknologi yang telah ada. Metode yang dipakai dalam proyek ini adalah Metode Behavior Setting, yakni dengan melakukan pengamatan terhadap pola perilaku masyarakat sekitar yang didukung dengan metode lain seperti melakukan pemetaan terhadap pola pergerakan manusia dan tempat yang menjadi tujuan dari pergerakan tersebut. Dengan metode ini, diharapkan dapat menciptakan program yang sesuai dengan kebiasaan yang ada di masyarakat. Hasil yang diperoleh ialah berupa sebuah third-place dengan program utama rekreasi air, dan didukung oleh program pendukung seperti food-street, waterfront garden, pertunjukkan budaya, dan komersial yang sesuai dengan kebutuhan masayarakat sekitar.
\end{abstract}

Kata kunci: behavior setting; rekreasi air; third-place

\begin{abstract}
The rapid development of the population in this current era leads the growing population density. In daily life, we know the terms of first-place and second-place (the place of work/school). As the era developments, each function of first-place and second-place is often combined and in the end it has no clear separation of functions between the two. From the issue, comes third-place to be an intermediate space between first-place and secondplace to host activities that should be done outside of the both places. Bekasi as one of the most populous city in Indonesia has a large potential source such as Irrigation Channels Kalimalang which can be utilized as recreational facilities and also water treatment as an educational platform for the community and utilize existing technology. The method used in this project is the Behavior Setting Method, by observing the behavior patterns of surrounding communities supported by other methods such as mapping the pattern of human movements and the place that is the goal of the movement. With this method, the goals that we hoped is we can create a program that fits the habits of the community. The results obtained are a third-place with the main water recreation program, and supported by supporting program such as food-street, waterfront garden, cultural show, and commercial to suit the needs of the surrounding community.
\end{abstract}

Keywords: behavior setting; third-place; water recreation

\section{PENDAHULUAN}

Di era sekarang ini, fungsi dari first-place seringkali membaur dengan second-place. Hal ini menyebabkan fungsi yang seharusnya tergantikan oleh fungsi lain yang seharusnya tidak 
terdapat pada tempat tersebut. Selain itu, terdapat pula aktivitas yang tidak ideal pada suatu tempat dan menyebabkan kejenuhan atau kepenatan yang terjadi di dalam masyarakat karena fungsi yang seharusnya menjadi tempat tinggal, telah membaur dengan fungsi second-place sebagai tempat bekerja. Tidak ada lagi kejelasan dari fungsi dari masing-masing tempat. Hal ini yang membentuk sebuah third-place, tempat yang menjadi perantara bagi first-place dan second place untuk melakukan kegiatan lain di luar kedua kategori tempat tersebut.

Bekasi yang merupakan salah satu kota terpadat di Indonesia memiliki beberapa potensi yang dapat dimanfaatkan untuk mengatasi permasalahan tersebut. Bekasi Selatan merupakan kecamatan di Kota Bekasi yang menjadi pusat kota, sehingga pembangunan banyak terfokus pada Bekasi Selatan. Salah satu potensi yang dapat dimanfaatkan ialah Saluran Irigasi Kalimalang yang merupakan salah satu sumber air terbesar yang ada di Bekasi. Saluran Irigasi Kalimalang dapat dimanfaatkan menjadi sarana rekreasi air dan juga pengolahan air yang dapat menjadi edukasi bagi masyarakat.

Sarana rekreasi air yang menjadi proyek utama akan terbentuk berdasarkan pola perilaku dan kebiasaan yang ada di masyarakat sekitar supaya dapat membentuk sebuah tempat yang nyaman bagi para pengunjung dan juga diharapkan dapat menjadi identitas bagi masyaraat Kota Bekasi, khususnya Bekasi Selatan. Sarana rekreasi air ini akan didukung oleh beberapa program penunjang yang merupakan jawaban dari permasalahan lain yang ada di masyarakat seperti banyaknya pedagang kaki lima dan parkir liar yang menggangu ketertiban jalan.

Visi dari proyek ini yaitu menjamin kehidupan yang sehat serta mendorong segala kesejahteraan bagi semua orang di segala usia, menjamin ketersediaan dan pengelolaan air serta sanitasi yang berkelanjutan bagi semua orang, menjamin akses energi yang terjangkau, terjamin, berkelanjutan, serta modern bagi semua orang, dan menjamin pola produksi dan konsumsi yang berkelanjutan (Eko, S., 2015 (Panduan SGDs)). Dapat disimpulkan bahwa visi dari proyek ini adalah untuk menjamin kehidupan yang sejahtera di dalam masyarakat dengan usaha-usaha tertentu untuk memenuhi kebutuhan masyarakat.

Selain visi proyek ini juga memiliki beberapa misi antara lain adalah

a. Menciptakan sebuah identitas bagi masyarakat Kota Bekasi dengan memanfaatkan potensi yang telah ada

b. Menyediakan sarana untuk memanfaatkan sumber potensi air yang ada untuk menciptakan sebuah energi baru yang aman bagi lingkungan, khususnya untuk Bekasi Selatan.

c. Menyediakan ruang terbuka hijau bagi masyarakat dikarenakan Kota Bekasi belum memiliki sarana penghijauan yang cukup (dari $30 \%$, baru $15 \%$ yang baru terpenuhi).

d. Menyerap tenaga kerja untuk mengurangi angka pengangguran di Kota Bekasi yang cuup tinggi.

e. Membentuk program-program yang dapat menjadi daya tarik bagi masyarakat dan mampu merangkul komunitas di sekitar Bekasi Selatan untuk dapat ikut serta dalam proyek tersebut.

\section{KAJIAN LITERATUR}

Kajian teoritikal berisikan tentang pemahaman tentang open architecture, serta teori-teori dari Ray Oldenburg, Doreen Massey, dan Edward Soja, yang dapat menjadi acuan dalam proyek third-place.

\section{Pemahaman tentang Open Architecture}

(Sumber : Kuliah "Open Architecture" oleh Bapak Suwardana Winata, S.T., M. Arch. (Jumat, 28 Juni 2019))

Arsitektur selalu mengalami perkembangan dalam perjalanannya, perkembangan ini muncul seiring adanya perkembangan dalam masyarakat. Arsitektur merupakan hasil rancangan dan karya yang berasal dari ciptaan manusia, dan tidak terbentuk dengan sendirinya. Dalam dunia arsitektur, terdapat tiga komponen dalam kehidupan yang dikenal sebagai first-place, second-place, dan third-place. First-place merupakan kehidupan di rumah yang di dalamnya 
berisikan interaksi antara anggota keluarga, bersifat privat, terstruktur, terkontrol, dan adanya keterbatasan untuk berekspresi. Second-place adalah kehidupan di tempat bekerja, di dalamnya terdapat interaksi antara pekerja, lebih kaku atau formal, terstruktur, diburu oleh waktu, dan juga terdapat pengalaman sosial. Third-place adalah kehidupan masyarakat diluar rumah, dan juga di luar tempat bekerja. Third-place ini bersifat netral, akses yang mudah, sederhana, percakapan sebagai aktivitas utama, dan lebih mengarah kepada interaksi dengan orang asing (strangers) atau komunitas.

Open Architecture merupakan the third-place bagi masyarakat kota, yang berfungsi sebagai ruang antara, dimana bukan merupakan tempat tinggal maupun tempat untuk bekerja. Untuk penjelasan yang lebih merinci, open architecture merupakan sebuah sistem yang terbuka dan mampu beradaptasi dengan kepentingan tertentu, dimana di dalamnya terdapat program utama yang didukung oleh beberapa program pendukung untuk dapat melayani masyarakat perkotaan yang menuntut kehidupan yang serba cepat, dinamis, efisien, dan praktis. Masalahmasalah yang terjadi di dalam masyarakat dapat terselesaikan dengan sebuah strategi desain. Third-place ini ditujukan untuk mengembalikan fungsi dari masing-masing tempat untuk mengembalikannya kepada aktivitas yang semestinya dan sebagai wadah untuk masyarakat dapat saling berinterakasi dan menghilangkan kepenatan.

\section{Teori dari Para Ahli \\ Ray Oldenburg}

Dalam bukunya (The Great Good Place, 1989), Oldenburg menunjukkan bahwa untuk mendapatkan sebuah kehidupan yang sehat, masyarakat harus hidup dalam tiga komponen keseimbangan, yakni kehidupan di rumah (first-place), di tempat kerja (second-place), serta kehidupan sosial di antara masyarakat itu sendiri. Kebudayaan lain seperti Kebudayaan Perancis memiliki istilah lain untuk menggambarkan ketiga komponen tersebut. Meskipun Bahasa Inggris-Amerika belum menemukan kosa kata yang cocok untuk ketiga komponen tersebut, tapi Oldenburg menyebutnya sebagai third-place dalam keseluruhan isi bukunya. Selain memiliki banyak manfaat, Oldenburg mengatakan bahwa third-place beperan penting dalam nilai sosial dan juga dalam sejarah.

Oldenburg menyebutkan bahwa third-place diperlukan bagi setiap orang untuk melepaskan kepenatan yang berasal dari aktivitas keseharian mereka. Menurut Ray Oldenburg, ada delapan karakteristik dari third-place, diantaranya bersifat netral, leveler, conversation, accessible and accomodation, regular, low profile, mood is playful, dan home away from home.

Dari teori yang dikemukakan oleh Ray Oldenburg, hal yang dapat dijadikan acuan dalam proyek ini adalah menciptakan sebuah third-place yang memenuhi karakteristik yang dikemukakan oleh Ray Oldenburg. Dengan memenuhi karakteristik tersebut, permasalahan akan fungsi sebuah tempat yang seringkali terbaur dapat diatasi.

\section{Doreen Massey}

Menurut Massey (1994), tempat memiliki tiga karakteristik utama. Pertama, tempat merupakan hasil dari aktifitas manusia. Kedua, tempat bersifat dinamis. Ketiga, tempat hanya dapat dipahami sepenuhnya melalui interaksinya dengan tempat lain, sejalan dengan pengertian geografi manusia. Dalam bukunya yang berjudul For Space, Massey (2005) menulis untuk menghidupkan kembali space, untuk mendinamiskannya, membuatnya menjadi lebih relevan, dan menekankan betapa pentingnya space dalam kehidupan dan organisasi sosial kita. Massey menjabarkan bahwa space dan place tidak memiliki aturan yang mengikat. Dalam buku tersebut, Massey menceritakan pandangannya bahwa segala sifat keterbukaan merupakan sesuatu yang patut dilakukan untuk terciptanya sebuah keharmonisan. Kita yang hidup di wilayah perkotaan akan hidup secara bersama-sama dengan suatu tata cara yang dilakukan secara bersama-sama dan telah menjadi kebiasaan yang harus dipatuhi di suatu tempat.

Open architecture dapat dilihat sebagai suatu arsitektur yang terbuka dan dapat menjadi wadah bagi ruang sosial masyarakat yang menjadikan keterbukaan sebagai kunci utama 
keberhasilan terbentuknya ruang sosial tersebut. Selain itu, Massey memiliki ungkapan yang dapat dijadikan sebagai referensi yakni "Identitas dari sebuah tempat adalah seperti bagaimana seorang ibu dapat berfungsi sebagai tempat yang simbolis bagi "anak-anak nakal" untuk kembali ketika tidak ada tempat lain untuk dituju." Hal ini membuktikan bahwa identitas kawasan akan menjadi ciri yang akan selalu diingat oleh masyarakat dan membedakanya dengan tempat lainya.

\section{Edward Soja}

Soja (1996) telah menyusun suatu teori mengenai "ruang ketiga"/ thirdspace. Menurutnya, segala sesuatu selalu datang bersamaan, sebagaimana subjektivitas dan objektivitas, abstrak dan konkret, nyata dan imajinasi, yang dapat diketahui dan yang tak terbayangkan, pengulangan yang sama dan perubahan yang berbeda, struktur dan lembaga, pemikiran dan tubuh, kesadaran dan ketidaksadaran, disiplin ilmu dan transdisiplin ilmu, kehidupan sehari-hari dan sejarah yang tak berakhir". Soja menjelaskan bahwa thirdspace (ruang ketiga) dilihat sebagai suatu cara pemahaman dan tindakan "lain" yang mengubah spasialitas kehidupan manusia atau sebagai sesuatu mode yang berbeda dari kesadaran keruangan kritis, yang sesuai dengan ruang lingkup dan signifikansi baru dibawa oleh trialektik diseimbangkan dari aspek keruangan-sosial-historis (Soja, 1996).

Seiring perkembangan, konsep trialectics yang dikemukakan oleh Henri Lefebvre dikembangkan oleh Soja, dimana konsep ruang yang diproduksi dalam mesyarakat melalui proses triadic yang terdiri dari ruang praktik (ruang secara fisik), representasi ruang (ruang dalam alam pikiran), dan ruang representasi (ruang sebagai sesuatu yang nyata dan dibayangkan). Dari teori yang dikemukakan oleh Soja, dapat disimpulkan bahwa dalam melihat sebuah space tidak hanya sebatas ruang, namun terdapat pula pengalaman secara psikologis yang dapat menjadi daya tarik tersendiri bagi sebuah third-place nantinya, sehingga masyarakat dapat merasakan sesuatu yang menarik dari segi psikologisnya dan menjadikan proyek thirdplace ini akan memiliki identitas tertentu dari pengalaman-pengalaman psikologis ruang yang dirasakan oleh pengunjungnya.

\section{Kesimpulan Teori}

Sebuah third-place harus memenuhi segala karakteristik yang dikemukakan oleh Ray Oldenburg untuk dapat menciptakan sebuah third-place yang sesuai dengan kebutuhan masyarakat perkotaan saat ini dan untuk mencapai titik sustainable yang diperlukan dalam kehidupan perkotaan. Sebuah third-place selain dihadirkan secara fisik, namun juga dapat dihadirkan dengan sebuah identitas yang memperkuat kaakteristik third-place dan dapat menjadi daya tarik dari third-place tersebut supaya manusia dapat menjadikannya sebuah tempat yang simbolis (Doreen Massey). Selain itu, third-place diharapkan menjadi tempat yang dapat memberikan pengalaman secara psikologis, sehingga selain memberikan sesuatu yang nyata, namun juga dapat memberikan sesuatu yang imajiner atau hanya dapat dirasakan secara psikologis (Edward Soja).

\section{METODE}

\section{Metode Behavior Setting}

Dalam pemenuhan kebutuhan manusia yang sesuai diuraikan Maslov dalam hierarki kebutuhan, terlihat adanya pola perilaku para penggunanya. Barker (1968) seorang tokoh psikologi ekologi yang mengembangkan penelitian prilaku individual dilapangan, menelusuri pola perilaku manusia berkaitan dengan tatanan lingkungan fisiknya, dan melahirkan konsep "tatar atur" (behavior seting). Menurut Barker (1968) dalam Laurens (2004:131), behaviour setting di sebut juga dengan "tatar perilaku" yaitu pola perilaku manusia yang berkaitan dengan tatanan lingkungan fisiknya. Senada dengan Haviland (1967) dalam Laurens (2004:131) bahwa tatar perilaku sama dengan "ruang aktivitas" untuk menggambarkan suatu unit hubungan antara perilaku dan lingkungan bagi perancangan arsitektur. 


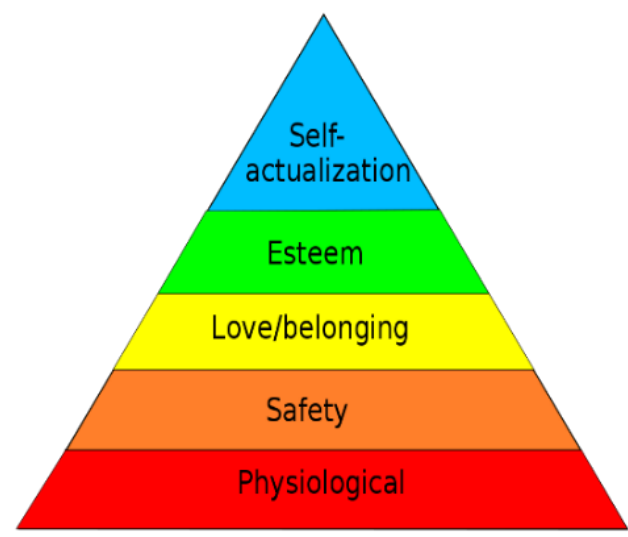

Gambar 1 Hierarki Kebutuhan (Maslov)

Sumber: Wikipedia, 2019

Laurens (2004:184) menyebutkan dalam pengamatan behavior setting, dapat dilakukan analisis melalui beberapa cara, antara lain sebagai berikut:

a. Mengunakan Time Budget

Time Budget memungkinkan orang mengurai/mendekomposisikan suatu aktivitas seharihari, aktivitas mingguan atau musiman, kedalam seperangkat behavior setting yang meliputi hari kerja mereka, atau gaya hidup mereka (Michelson dan Reed, 1975).

b. Studi Asal dan Tujuan

Studi asal dan tujuan adalah suatu studi yang mengamati, mengidentifikasi awal dan akhir dari pola - pola pergeraan. Studi semacam ini menggambarkan pola perilaku yang sesungguhnya terjadi, bukan hanya seperti yang dibayangkan oleh arsitek, melainkan yang membentuk kehidupan seseorang atau sekelompok orang. Studi asal dan tujuan merupakan pendekatan yang dapat diterapkan pada skala tahun atau skala bangunan. Terdapat dua model pengamatan atau observasi dalam penelitian arsitektur dan perilaku manusia, yaitu model dengan metode place centered (pemetaan tempat tujuan dari pergerakan manusia) dan person centered map (pemetaan pergerakan manusia).

c. Kuisioner

Metode yang selanjutnya dipakai untuk pemilihan program ialah kuisioner, melakukan menyebarkan kuisioner kepada penduduk yang tinggal di sekitar area tapak dan mencari tahu apa yang sebenarnya dibutuhkan oleh masyarakat sekitar untuk mengatasi segala permasalahan kota yang terjadi.

Metode selanjutnya yang dipakai sebagai metode desain adalah metode berkonteks dengan lingkungan, yakni dengan menyesuaikan desain dengan keadaan lingkungan sekitar dan memperhatikan segala aspek lingkungan yang ada di sekitar lokasi tapak, serta mengangkat isuisu yang terjadi dimasyarakat dan dijadikan sebagai sebuah jawaban desain untuk mengatasi isuisu tersebut.

\section{DISKUSI DAN HASIL}

\section{Penerapan Teori Dari Para Ahli}

Berdasarkan teori dari para ahli, dapat disimpulkan bahwa sebuah third-place memiliki beberapa karakteristik yakni bersifat netral, berfugsi sebagai sebuah identitas bagi masyarkat sekitarnya, dan juga selain memberikan pengalaman secara fisik, juga dapat memberikan pengalaman secara psikologis bagi para pengunjung.

Bekasi Selatan memiliki salah satu sumber potensi air yang dapat dimanfaatkan sebagai sarana rekreasi air, yakni Saluran Irigasi Kalimalang. Sarana rekreasi air ini dapat menjadi identitas bagi masyarakat Kota Bekasi, membentuk pengalaman psikologis bagi masyarakat 
(program yang terbentuk berdasarkan hasil dari pola perilaku masyarakat sekitar yang memang sudah menjadi kebiasaan), dan juga sebuah tempat yang netral, mengingat Bekasi Selatan merupakan pusat kota, sehingga seluruh kegiatan penduduk dari Kota Bekasi sebagian besar berpusat di Bekasi Selatan.

\section{Konsep Dan Desain}

Kategori program ruang yang diusulkan untuk proyek Sarana Rekreasi Air ini adalah kategori hospitality sebagai fungsi utama, dan didukung oleh kategori entertainment dan commercial sebagai fungsi pendukung atau sebagai daya tarik bagi para pengunjung. Program-program tersebut akan dijelaskan secara lebih rinci sebagai berikut:

a. Rekreasi Air

Rekreasi air terdiri dari dua aspek, yakni dari aspek olahraga dan juga aspek pengolahan air. Water recreate diharapkan dapat menjadi wadah untuk sarana rekreasi dan komunitas olahraga air lainnya yang belum memiliki wadah untuk berlatih, selain itu water recreate diharapkan dapat menjadi sarana edukasi bagi masyarakat sekitar akan pentingnya air serta bagaimana pengolahan air yang baik dan benar.

b. Waterfront Garden

Waterfront Garden ini diharapkan dapat membantu Kota Bekasi dalam memenuhi angka minimal dari RTH yang diperlukan, sekaligus pengunjung dapat menikmati area Kalimalang sehingga dapat mengubah image Kota Bekasi yang gersang menjadi lebih asri.

c. Food Street

Food street diharapkan dapat menampung pedagang kaki lima yang masih berada di sekitar tapak, demi terciptanya sebuah tatanan kota yang lebih baik.

d. Pertunjukkan Budaya

Banyak dari masyarakat Bekasi yang belum mengetahui bahwa Bekasi memiliki kebudayaan tersendiri. Hal ini dikarenakan budaya Bekasi merupakan hasil akulturasi dari kebudayaan Betawi dan juga kebudayaan Sunda. Belum banyak yang tahu jika tari topeng yang dikenal sebagai adat Betawi ternyata ditemukan pertama kali di daerah Tambun, Bekasi. Namun masyarakat Bekasi tidak dapat melawan klaim tersebut karena masyarakat Bekasi pun merupapak hasil akulturasi dari berbagai kebudayaan. Program ini diharapkan dapat memberi edukasi kepada masyarakat Kota Bekasi untuk dapat menjaga budayanya.

e. Komersial

Area komersial dijadikan sebagai pelengkap sekaligus daya tarik bagi pengunjung untuk dapat memenuhi kebutuhan dari masyarakat.

Berikut adalah persentase program yang dijelaskan dalam bentuk grafik:

\section{Persentase Program}

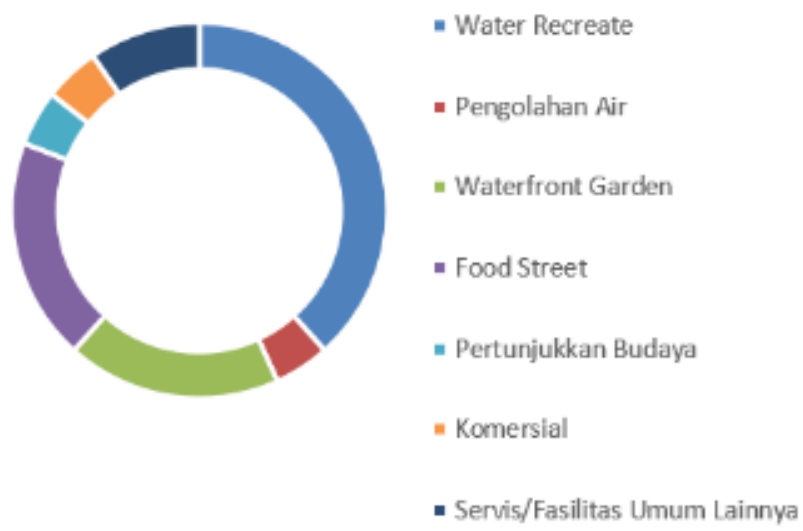

$2058 \mathrm{~m} 2 / 35 \%$

$257,25 \mathrm{~m} 2 / 5 \%$

$990 \mathrm{~m} 2 / 15 \%$

$1029 \mathrm{~m} 2 / 20 \%$

$257,25 \mathrm{~m} 2 / 5 \%$

$257,25 \mathrm{~m} 2 / 5 \%$

$514,5 \mathrm{~m} 2 / 40 \%$

Gambar 2. Persentase Program

Sumber: Penulis, 2019 
Adapun program ruang akan dijelaskan secara rinci dengan rincian sebagai berikut:

Tabel 1 Tabel program ruang

\begin{tabular}{|c|c|c|c|c|c|c|}
\hline Program & Nama Ruang & $\begin{array}{c}\text { Kapasitas } \\
\text { per } \\
\text { ruang }\end{array}$ & $\begin{array}{l}\text { Luas per } \\
\text { ruang }\end{array}$ & $\begin{array}{l}\text { Jumlah } \\
\text { Ruang }\end{array}$ & Sirkulasi & $\begin{array}{c}\text { Luasan } \\
\text { Total }\end{array}$ \\
\hline \multirow{3}{*}{$\begin{array}{c}\text { Water } \\
\text { Recreate }\end{array}$} & Pemancingan & 200 & $340 \mathrm{~m} 2$ & - & \multirow{3}{*}{$617 \mathrm{~m} 2$} & $340 \mathrm{~m} 2$ \\
\hline & $\begin{array}{c}\text { Area Water } \\
\text { Sport }\end{array}$ & 800 & $800 \mathrm{~m} 2$ & - & & $800 \mathrm{~m} 2$ \\
\hline & $\begin{array}{c}\text { Area Perahu / } \\
\text { Kano }\end{array}$ & 100 & $300 \mathrm{~m} 2$ & - & & $300 \mathrm{~m} 2$ \\
\hline $\begin{array}{c}\text { Pengolahan } \\
\text { Air }\end{array}$ & $\begin{array}{c}\text { R. Reverse } \\
\text { Osmosis }\end{array}$ & - & $200 \mathrm{~m} 2$ & & $57 \mathrm{~m} 2$ & $257 \mathrm{~m} 2$ \\
\hline $\begin{array}{l}\text { Waterfront } \\
\text { Garden }\end{array}$ & Area Hijau & 900 & $693 \mathrm{~m} 2$ & & $297 \mathrm{~m} 2$ & $990 \mathrm{~m} 2$ \\
\hline \multirow[t]{2}{*}{ Food Street } & Kios Makanan & 10 & $24 \mathrm{~m} 2$ & 10 & \multirow[b]{2}{*}{$308 \mathrm{~m} 2$} & $240 \mathrm{~m} 2$ \\
\hline & Area Makan & 200 & $481 \mathrm{~m} 2$ & & & $\begin{array}{l}1029 \\
\mathrm{~m} 2\end{array}$ \\
\hline \multirow[t]{2}{*}{$\begin{array}{l}\text { Pertunjukkan } \\
\text { Budaya }\end{array}$} & $\begin{array}{l}\text { Area } \\
\text { Pertunjukkan }\end{array}$ & 10 & $150 \mathrm{~m} 2$ & & \multirow{2}{*}{$77 \mathrm{~m} 2$} & $150 \mathrm{~m} 2$ \\
\hline & R. Persiapan & 5 & $30 \mathrm{~m} 2$ & & & $30 \mathrm{~m} 2$ \\
\hline \multirow[t]{2}{*}{ Komersial } & Area Toko & 20 & $50 \mathrm{~m} 2$ & & \multirow{2}{*}{$77 \mathrm{~m} 2$} & $50 \mathrm{~m} 2$ \\
\hline & Area Duduk & 30 & $130 \mathrm{~m} 2$ & & & $130 \mathrm{~m} 2$ \\
\hline \multirow{10}{*}{ Area Servis } & $\begin{array}{l}\text { Tempat } \\
\text { Sholat }\end{array}$ & 20 & $\begin{array}{l}1.3 \quad x \\
0.75 \mathrm{~m} 2\end{array}$ & & \multirow{10}{*}{$37,6 \mathrm{~m} 2$} & $19.5 \mathrm{~m} 2$ \\
\hline & $\begin{array}{l}\text { Tempat } \\
\text { Wudhu }\end{array}$ & 10 & $0.8 \mathrm{~m} 2$ & & & $8 \mathrm{~m} 2$ \\
\hline & $\begin{array}{l}\text { Ruang } \\
\text { Karyawan }\end{array}$ & 15 & $42 \mathrm{~m} 2$ & & & $42 \mathrm{~m} 2$ \\
\hline & R. Genset & - & $32 \mathrm{~m} 2$ & & & $27 \mathrm{~m} 2$ \\
\hline & Toilet & - & $205 \mathrm{~m} 2$ & & & $105 \mathrm{~m} 2$ \\
\hline & $\begin{array}{l}\text { Ground } \\
\text { Reservoir }\end{array}$ & & $22 \mathrm{~m} 2$ & & & $22 \mathrm{~m} 2$ \\
\hline & STP & - & $22 \mathrm{~m} 2$ & & & $44 \mathrm{~m} 2$ \\
\hline & $\begin{array}{l}\text { R. } \\
\text { Maintenance }\end{array}$ & & $72 \mathrm{~m} 2$ & & & $72 \mathrm{~m} 2$ \\
\hline & R. Pompa & - & $10 \mathrm{~m} 2$ & & & $10 \mathrm{~m} 2$ \\
\hline & R. Panel & - & $27 \mathrm{~m} 2$ & & & $27 \mathrm{~m} 2$ \\
\hline \multicolumn{2}{|c|}{ Perkiraan Luas Total } & & & & & $5415 \mathrm{~m} 2$ \\
\hline
\end{tabular}




\section{PROSES GUBAHAN MASSA}

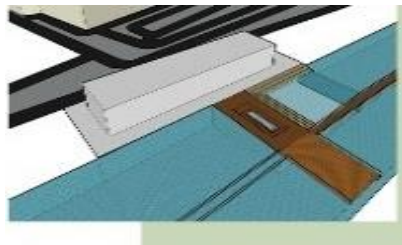

Gubahan disesuaikan mengikuti GSB dan CSS yang berlaku sehingga massa bangunan menjadi pipih

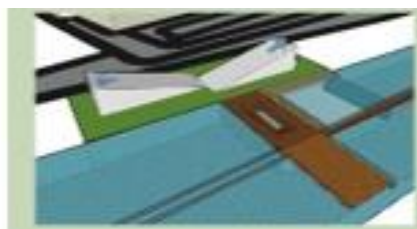

Peningglan pada baglan kanan dan kiri massa untuk pemaksimalan view Kalimalang yang dapat dinikmati pengunjung

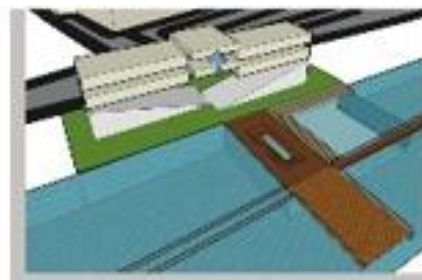

Level tipikal karena adanya kesamaan fungsi pada level tsb

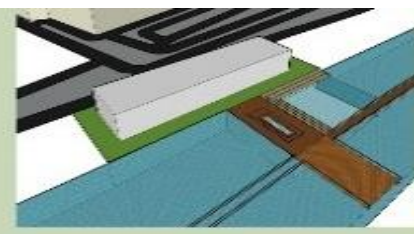

Area di luar gubahan massa pada tapak menjadi greenbelt untuk emenuhi jumlah minimal KDH yang berlaku

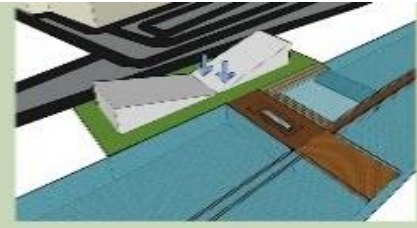

Penekanan massa sebagai tanda entrace, suoaya entrance tidak terkesan teruttup dan kaku

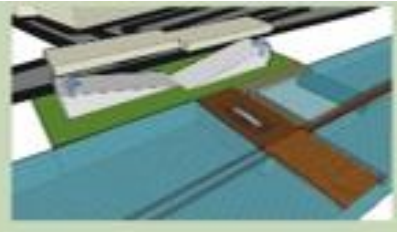

Level atas yang mengikuti pola dari bagian dasar bangunan (menglkuti ketentuan CSB dan cSS yang berlaku)

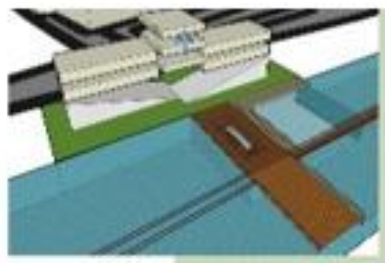

Level teratas menandai yang utama pada masa bangunan

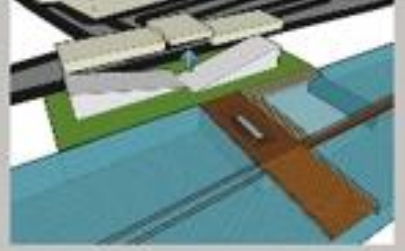

Split level pada masa tengah sebagai eye catching dari massa bangunan

yang menjadi massa utama

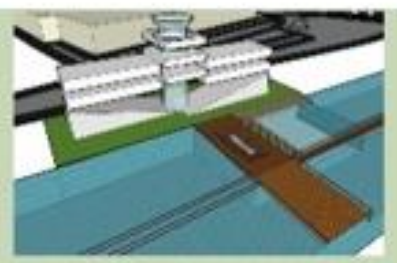

Penambahan waterfall sebagai icon dari tapak

Gambar 3. Proses Gubahan Massa

Sumber: Penulis, 2019

\section{ZONASI BANGUNAN}

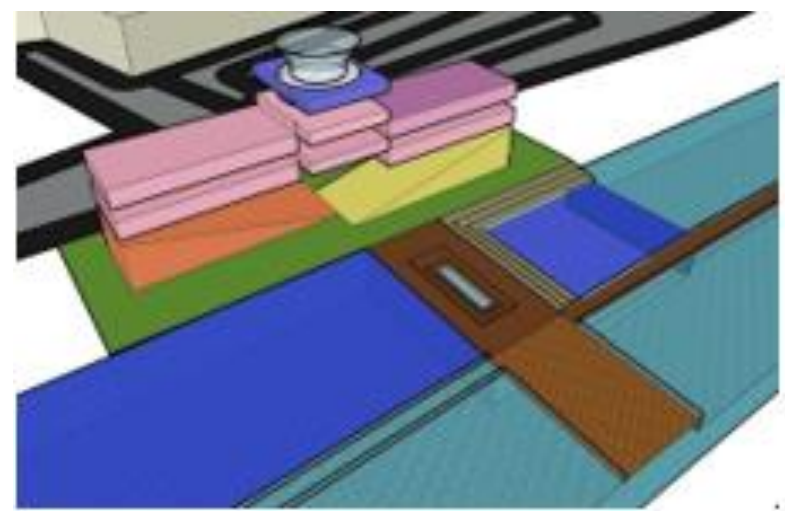

\section{Keterangan :}

Area Water Recreation

Area Komersial

\section{Area Servis}

Area Food Street

Gambar 4. Zonasi Bangunan

Sumber: Penulis, 2019 


\section{KESIMPULAN DAN SARAN}

Sarana Rekreasi Air di Bekasi Selatan hadir untuk mengatasi banyak kekeliruan yang terjadi antara fungsi dari first-place dan second-place. Fungsi diantara keduanya seringkali menyatu yang menyebabkan ketidaksesuaian aktivitas yang seharusnya ada pada first-place dan secondplace. Sarana Rekreasi Air di Bekasi Selatan sebagai ruang antara bagi keduanya. Sarana Rekreasi Air di Bekasi Selatan menjadi jawaban atas permasalahan yang terjadi dan menjadi tempat yang nyaman bagi masyarakat.

Metode yang digunakan ialah behavior setting, yakni metode yang mengamati pola perilaku dari masyarakat. Dari metode tersebut, terbentuklah beberapa program, yakni program water recreate sebagai program utama dan didukung oleh program lainnya seperti food street, pertunjukkan budaya, dan pertunjukkan kesenian. Program-program ini berdasarkan kebiasaan dan pola perilaku masyarakat yang ada di Kota Bekasi, khususnya Bekasi Selatan. Sarana Rekreasi Air di Bekasi Selatan menjadi sebuah identitas baru bagi masyarakat Kota Bekasi dengan memanfaatkan sumber potensi air yang besar di Saluran Irigasi Kalimalang. Sarana Rekreasi Air di Bekasi Selatan ini akan mendeskripsikan segala kebutuhan masyarakat yang disesuaikan dengan pola kehidupan sehari-hari mereka.

Adapun saran yang diberikan oleh penulis ialah sebuah third-place seharusnya menjadi sebuah tempat netral yang dapat menjadi wadah bagi semua orang dan dapat menjadi jawaban atas isu-isu yang ada dalam masyarakat sekitar.. Penulis menyadari bahwa masih terdapat banyak kekurangan dalam jurnal ini, oleh karena ini penulis membutuhkan kritik dan saran yang membangun dari para pembaca.

\section{REFERENSI}

Eko, S. (2015). Panduan SDGs. [Electronic version]. Jakarta: International NGO forum on Indonesian Development.

Laurens, J. M. (2004). Arsitektur dan Perilaku Manusia. Jakarta: PT Grasindo

Massey, D. B (2005). For Space. London: Sage

Michelson, W. dan Reed, P. (1975). "The Time Budget". dan Michelson, W. (Eds)

Oldenburg, R. (1989). The Great Good Place. New York: Marlowe \& Company.Soja, E. W.

(1996). Thirdspace. Malden (Mass.): Blackwell.

Schoggen, P. (1989). Behavior Settings: A Revision and Extension of Roger G. Barker's Ecological Psychology. Stanford: Stanford University.

Winata, S. (2019). Open Architecture. Materi Kuliah Stupa 8 Prodi 1 Arsitektur UNTAR, Jakarta (Jumat, 28 Juni 2019) 
